DOI 10.15826/qr.2016.2.159

УДК 791-21(470)+791.233:316.74

\title{
ASPIRATIONS OF HOME IN POST-SOVIET RUSSIA: DOMESTIC SPACES AND NATIONAL RESONANCES IN ANDREY ZVYAGINTSEV'S ELENA*
}

\author{
Andrew McGregor \\ Robert Lagerberg \\ School of Languages and Linguistics, \\ University of Melbourne, \\ Australia
}

This article analyses the role of domestic living space and its connection with identity in the Russian feature film Elena (Andrey Zvyagintsev, 2011), winner of the Grand Jury Prize at the 2011 Cannes Film Festival. The film uses a spatially symmetrical structure based on two separate apartments frequented by the film's eponymous heroine, both of which represent distinct socioeconomic and historical aspects of Soviet and Post-Soviet life. The first is Elena's husband's large, modern, upmarket and centrally located apartment that is as cold, tomb-like and indeed lifeless as it is chic. The second is her son's older, tiny, squalid relic of the Soviet past situated on the periphery, with its claustrophobic walls providing a sense of human contact and warmth, despite its toxic air of decadence, indolence and violence. As in the earlier Russian film Little Vera (Vasili Pichul, 1988), it will be argued that in Elena, identity is inextricably linked with physical living space in a specifically Russian context. Elena is an ironic ode to the apartment, both Soviet and modern. Drawing on Marc Augés theory of the non-place, it will be argued that the universal aspiration to live in comfort, while human and understandable, is shown, in the post-Soviet landscape depicted by Zvyagintsev's powerful film, to result in a form of living death.

Keywords: (Post-)Soviet Russia; National Identity; Domestic Space; Elena; Andrey Zvyagintsev; Non-places; Marc Augé.

В статье анализируется роль домашнего пространства и его связь с идентичностью персонажей в российском игровом фильме «Елена» (режиссер Андрей Звягинцев, 2011), получившем специальный приз

* Citation: McGregor, A., Lagerberg, R. (2016). Aspirations of Home in Post-Soviet Russia: Domestic Spaces and National Resonances in Andrey Zvyagintsev's Elena. In Quaestio Rossica. Vol. 4. № 2, p. 80-94. DOI 10.15826/qr.2016.2.159.

Цитирование: McGregor A., Lagerberg R. 1968: Aspirations of Home in Post-Soviet Russia: Domestic Spaces and National Resonances in Andrey Zvyagintsev's Elena // Quaestio Rossica. Vol. 4. 2016. № 2. P. 80-94. DOI 10.15826/qr.2016.2.159.

(C) McGregor A., Lagerberg R., 2016 Quaestio Rossica • Vol. 4 • 2016 • № 2, p. 80-94 
жюри программы «Особый взгляд» Каннского кинофестиваля в 2011 г. Действие фильма происходит в двух симметричных пространствах квартирах, в которых бывает героиня фильма. Оба пространства представляют разные социально-экономические и исторические аспекты советской и постсоветской жизни. Первое - большая дорогостоящая современная квартира мужа Елены, расположенная в центре города: эта квартира холодна, подобно склепу, и безжизненна в своей изысканности. Второе пространство - квартира сына Елены - крохотное убогое жилище времен советского прошлого, расположенное вдалеке от центра города, тесное, но дающее почувствовать близость и человеческое тепло, несмотря на спертую атмосферу упадка, праздности и насилия. Подобно тому, как это происходит в фильме «Маленькая Вера» (режиссер Василий Пичул, 1988), идентичность персонажей в «Елене» неразрывно связана с физическим пространством, в котором они живут, в специфическом русском контексте. «Елена» - ироническая ода квартире, как советской, так и современной. Обращаясь к теории «ничейного пространства» Марка Оже, авторы пытаются доказать, что универсальное стремление к комфортной жизни, общечеловеческое и понятное, в постсоветском пространстве впечатляющего фильма А. Звягинцева изображено как смерть при жизни.

Ключевые слова: постсоветская Россия; национальная идентичность; пространство дома; «Елена»; Андрей Звягинцев; «ничейное пространство»; Марк Оже.

The aim of this article is to examine the role of domestic spaces essentially two apartments - in the Russian feature film Elena (Andrey Zvyagintsev, 2011), in particular their role in the ironic subversion of the messages implied in the film's surface structure. In this way the approach and findings of the present article resemble to some degree those of a previous paper [Lagerberg, McGregor] in which the apartment in the film Little Vera (Vasili Pichul, 1988) was shown to be both central to the film, as well as an ironic device used to undermine the more positive images of (apartment) living spaces in Soviet/Russian cinema. To the extent that the Soviet-era apartment (квартира) is such a fundamental and recognisable part of modern Russian culture, and its role so much to the forefront in the above-mentioned films, any discussion of it is ipso facto concerned with wider notions of Russian identity and nationality, which will also be discussed below in their turn.

Elena was screened in Competition at the 2011 Cannes International Film Festival, where it was awarded the prestigious Grand Jury Prize. The film was met with generally good critical acclaim at the Festival and in the media upon its release later that year. ${ }^{1}$ While a taut screenplay, good acting, intelligent cinematography and the music of Philip Glass accounted for much of that positive appraisal, the film also operates at a more complex level: ostensibly

\footnotetext{
${ }^{1}$ See, for example, the review in The Guardian newspaper: [Bradshaw]; or the "four star" ratings on the television show: [At the Movies].
} 
a film whose main storyline involves one family's upwardly-mobile move from a shabby, Soviet-era flat to a chic and spacious city apartment through the deadly machinations of the central and eponymous protagonist, Elena. This rather "idealistic" surface plot is, as we shall argue, negated by an implicit and subtle irony involving the two main living spaces of the film.

A theoretical approach which is particularly well suited to an analysis of cultural concepts connected with (domestic) spaces in the modern context is Marc Augés theory of non-places, as developed in his seminal work Non-Places: An Introduction to Supermodernity [Augé] ${ }^{2}$. This paper will, therefore, examine Elena in the light of Augés work, in particular the extent to which his theory of non-places may, in certain instances in this supermodern globalised world, be as applicable to the domestic space as it is to the increasingly ubiquitous public spaces of airports, hotels, shopping centres and other typical non-places. While the home may be defined as private and personal, as opposed to public and impersonal, it will be argued here that the domestic space, far from being a comforting and reassuring destination in itself, can be read as liminal [Thomassen, p. 322], as transitory, as a space "in-between" a departure from an apparently undesirable past situation or location and a perceived - and indeed illusory - arrival at a point of socially aspirational self-realisation.

Augé defines place as "relational, historical and concerned with identity". It stands to reason, therefore, that he should define non-place as "a space which cannot be defined as relational, or historical, or concerned with identity" [Augé, p. 63]. Augé hastens to point out, however, that the distinction between place and non-place is not to be imagined as a mutually exclusive binary opposition: "[The non-place] never exists in pure form; places reconstitute themselves in it; relations are restored and resumed in it... Place and non-place are rather like opposed polarities: the first is never completely erased, the second never totally completed; they are like palimpsests on which the scrambled game of identity and relations is ceaselessly written" [Augé, p. 64].

Indeed, as it shall be argued in this article in relation to the domestic space: "The possibility of non-place is never absent from any place" [Augé, p. 86]. The focus of this article is, then, on the peculiarly Russian evocation of what we shall argue are the non-places inhabited by the characters in two living spaces in the film Elena, and, therefore, we attempt a reinterpretation of the film as a somewhat pessimistic, sombre appraisal of modern Russian life and its Soviet roots, as well as a comment on the age-old debate which has focussed on Russia's identity and place in the world. At the heart of the argument is the fact that these two non-places are central to the identity and the motivations of the main characters and, indeed, account for the entire structure of the film and the vast majority of the scenes in it.

\footnotetext{
${ }^{2}$ Augés work was originally published in French in 1992 by Seuil under the title NonLieux, Introduction à une anthropologie de la surmodernité, which was subsequently translated into English and published in 1995 by Verso under the title Non-Places: Introduction to an Anthropology of Supermodernity. Reference in this article is made to the second edition of the English translation, which was published in 2008 by Verso.
} 


\section{Non-place 1: the modern apartment}

Both the plot and locational structure of Elena are strikingly symmetrical as each of them is determined by the two living spaces (the apartments) which bind Elena (who is herself the central link in both plot and location) psychologically and physically. The two apartments establish and develop the central theme of the film, namely the question of Russia's past and future identity (with the present an apparently perpetual liminal space of its own), the old and new, Soviet and Post-Soviet. The depiction of two apartments from different historical periods is representative of the linear progression of Russian history, yet, at the same time, this progression is caught in the particular Bakhtinian "time-space warp" of the film, Soviet and modern, as it were, juxtaposed both temporally and physically. The force of this is to open up the age-old debate about Russia's identity, going back to Petr Chaadaev's Philosophical Letter of 1836 in which he berated Russia's lack of

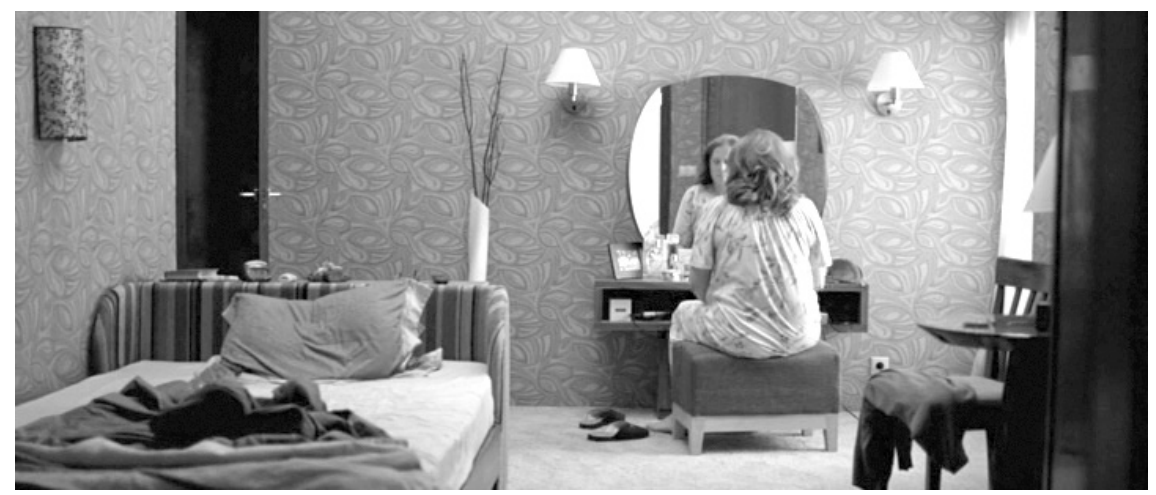

1. Elena's husband's apartment. Still from Elena. A. Zvyagintsev. 2011

national history and dignity, imbuing it with a new sense of post-colonial disconnectedness: "We do not belong to any of the great families of the human race; we are neither of the West nor of the East, and we have not the traditions of either. Placed, as it were, outside of time, we have not been touched by the universal education of the human race" [Chaadaev, p. 162]. Both the atmosphere of the Soviet-era apartment and the displaced "universality" of the modern apartment show two aspects of non-place respectively, nonplace as physically alienating living-space and non-place as aesthetically alienating living-space (Fig. 1). As Clowes puts it with reference to Chaadaev, "[C]haadaev's words eerily anticipate Julia Kristeva's image of the postcolonial condition when he asserted, 'we Russians' are 'strangers to ourselves"' [Chaadaev, p. 164; Clowes, p. 11]. Although, of course, Russia was not literally colonised, the Soviet era represents a period of cultural colonisation, with the post-Soviet period its post-colonial equivalent. The film explores contemporary identity by using the embodiment of the past 
(the older apartment) within the present time-space. As Augé observes, "individual and collective identity is always constructed in relation to and in negotiation with otherness", the latter here represented by the older apartment [Augé, p. 9].

The film opens (and closes - there will be more on this framing technique below) with a striking and lengthy shot of Vladimir's modern apartment as it awakens at dawn through the branches of a leafless tree and the rather sinister cawing of a crow. The living space - both this particular apartment as well as the motif of living space - thus appears as the central element from the very outset. The location for the setting is unknown. The apartment could be located in any city in Russia, and indeed the world. No human voice is heard for several minutes, even when the camera enters the apartment; language is absent. Indeed, there is no explicit mention during the entire film about its actual location, i. e. either what town or country it is set in. This universal quality of the apartment is also important. Its international appeal and amenity make it all the more characteristic of a non-place, and indeed we find ourselves "in a world where there is no longer an elsewhere" [Augé, p. 22]. We are not in some culturally specific Russian space in this apartment, making it all the more appealing for Elena's family seeking to escape the confines of their cramped and typically (culturally specific) Soviet apartment, and, at the same time, seeking to escape their and the nation's past.

As the camera moves from exterior to interior, the people who inhabit the apartment, Elena and her husband Vladimir, almost take second stage to the spacious apartment itself through which the camera is free to move and linger as it chooses. The series of long shots that serve to showcase the modern apartment, much like a feature article in the pages of Vogue Living magazine, resemble a still-life - aesthetically beautiful and yet seemingly impossible to live in, highlighted by the absence of any dialogue initially and the sense of the characters being almost strangers to themselves and their environment. The way the apartment is shot reflects "the spatial overabundance of the present", with the non-places of Augés supermodern world characteristically large in scale, dwarfing the human subject, and ensuring that "the dominant aesthetic is that of the cinematic longshot" [Augé, p. 13, 28]. This is the postscript to Soviet culture then, a curiously vapid yet comfortable world, where everything appears to be in place, but lacking any defining sense of realness.

At the film's opening we see the early morning routine of Elena and her husband Vladimir who, as we shall learn later, has been married before. Even without this knowledge, however, the strained, formal and artificial character of their marriage is apparent. All this is played out in the large, spacious, modern apartment that the wealthy Vladimir has acquired through his business interests. Elena's son Sergei, his wife Tatiana and their son Alexander meanwhile live in a shabby, Soviet-era apartment in a remote suburb to which Elena must travel at length on public transport. Sergei is desperate for Elena to get hold of a considerable sum of money to pay for 
his son to enter a private college so that he can avoid military conscription. Subsequently, Elena's husband (in one of the few scenes not involved with one of the two apartments) has a heart attack in a swimming pool, recovers, and, while still in hospital, has a meeting with his estranged daughter Yekaterina (from his previous marriage), a world-weary and cynical young woman whose aloofness seems to define a universal characteristic of modern youth rather than subscribe to a specifically Russian cultural context. After this meeting, Vladimir resolves to leave his daughter the lion's share of his will and tells Elena of his intention. Before the will is formalised, Elena decides she must kill her husband as a way of gaining access to at least some of his money and thus giving her grandson the chance to escape military service. After murdering Vladimir with an overdose of Viagra, a somewhat ironic end for a man wielding his power and virility with gusto late in life, Elena takes money from the safe to her son's family. After an extremely violent gang brawl in which Alexander is badly beaten up, the film ends with what can only be assumed to be the apparently permanent arrival of Sergei and his family in the spacious apartment of the late Vladimir.

After the initial longshot of Elena's (separate) bedroom, we are presented with a fragmented and fractured image of the protagonist looking at herself in the mirror, brushing her hair in a repetitive and despondent fashion. The image is reminiscent of François Truffaut's Antoine Doinel in his mother's bedroom in Les quatre cents coups (The 400 Blows) (1959) - another depiction of a protagonist who finds himself in a space in which he does not belong and who resorts to crime in order to escape his domestic and social predicament and find his own identity. The space of the modern apartment may well be universal in its appeal, but just as apparent is Elena's isolation in it, both within and beyond the confines of her marriage. As Augé puts it: "The current globality consists of networks that produce both homogenization and exclusion." Elena is alone both in her marriage and in the modern world. Her physical appearance, middle-aged and thickset with the requisite headscarf tied under her chin, suggests Soviet Russia, leaving Elena cutting a somewhat anachronistic figure in "a world thus surrendered to solitary individuality" [Augé, p. 9, 63].

Elena moves slowly through the house, opening doors with a noise which increasingly seems to suggest the heavy sound of a tomb being opened - important later when the reverse sound, the door to Vladimir's bedroom being closed, signals his imminent demise after he is poisoned and his apartment becomes his tomb. The irony is increased by the fact that Elena is his personal carer and a nurse by profession.

The wide space and lack of (human) movement which the apartment is able to give to the camera is utilised to the maximum: as Vladimir and Elena have breakfast together, the camera is able to take in with ease the entire length of the table at whose opposite ends they sit. The viewer is acutely aware of the magnitude of the space that separates the two characters. The composition of the shot places an empty chair in the centre of the frame, once again reminiscent of Truffaut's landmark film (1959), except 
that in this instance the protagonist occupying the chair is not the young Antoine Doinel, but rather the "spatial overabundance" [Augé, p. 28] that characterises the non-place in which the couple lives. Indeed, the fact that the camera is able to rest and take in the scene without movement highlights even more acutely the tense and unnatural tone of their dialogue and their slight movements and gestures. The intention of this opening scene is ironic: the modern, chic apartment, appearing at dawn from the city gloom as if the harbinger of a better future, is not a home to its two inhabitants; rather, it represents a non-place for them as they live out their dysfunctional lives and marriage within it. The marriage is essentially a sham, a convenience for both Vladimir and Elena. The dysfunctional balance is only disturbed when Elena attempts to extend the significance of their union to her own family. Then it becomes apparent the extent to which her marriage is a fantasy, sustained by the apartment in which she appears to be more of a maid and a nurse than a wife, living in her own quarters and performing her housekeeping tasks diligently and perfunctorily. What should be a triumphant movement up the social scale for her through the economic benefits of her marriage thus becomes like "[c]ertain places [that] exist only through the words that evoke them, and in this sense they are non-places, or rather, imaginary places: banal utopias, clichés" [Augé, p. 77].

The rendering of Elena's domestic space as a non-place is further evidenced by the juxtaposition of the scene involving her pottering in the kitchen with the shot of her standing immediately afterwards in the lift lobby outside the apartment. The décor is almost identical - modern, aesthetically pleasing and yet lifeless. Likewise, once she finds herself downstairs in the street, the streetscape appears just as universal, soulless and artificial. This exterior scene is reminiscent of Jacques Tati's 1967 film Playtime, for which Tati constructed an entire cityscape of homogenised modern buildings architecturally designed and engineered for a promising future, and yet assuring a dehumanising and unsettling present. When Elena boards the tram and then the train to visit Sergei and his family, we are in an even more universal and familiar non-place, sitting in silence with our physically and emotionally isolated protagonist whose constant movement between her two worlds betrays her stagnation: "The traveller's space may thus be the archetype of non-place" [Augé, p. 70]. It is interesting to note that the other archetypal non-places in the film also play similar roles: as Vladimir drives to the fitness centre in his plush car, he is strangely unable to tune the radio to any station which suits him - indeed, the impression is almost one of a man who owns a manifestly underused car. The outside world which he sees populated with ordinary working people and pedestrians is hermetically sealed from him just as the only audible sounds we can hear come from within the car. The fitness centre, though by no means empty, almost becomes the scene of his death as he suffers a heart attack while swimming, then flounders and floats on the surface of the water unnoticed for several moments before he is rescued. Finally, the hospital where he is, of course, brought back to health, has as its longest scene the dialogue 
between Vladimir and his adult daughter, a scene which makes clear the dysfunctional relationship between them and the almost nihilistic level of cynicism which has become the norm for his daughter. All these locations add to the general sense of unease and displacement which the characters of the film exhibit to some degree.

\section{Non-place 2: the Soviet apartment}

In order to reach Sergei's Soviet-era flat, Elena must traverse what can only be described as a no man's land flanked by forest on the one hand and the towering presence of Soviet-era (possibly nuclear) power installations on the other. The distance between the two apartments is clearly more than geographical. The contrast with Vladimir's apartment could not be greater: as Elena leaves Vladimir's building, she is given a polite greeting from the concierge on the ground floor, whereas upon arriving at Sergei's dilapidated, Soviet-era block of flats she is greeted by a rather intimidating group of youths, the same youths who will later be involved in a gang

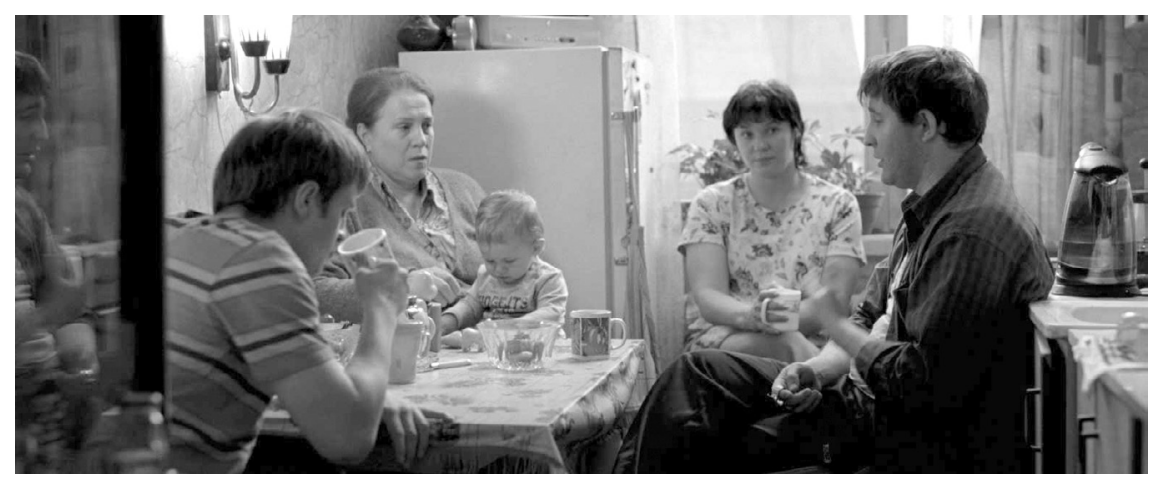

2. Elena's apartment. Still from Elena. A. Zvyagintsev. 2011

fight of extreme violence with Sergei's son Alexander in their midst. The framing technique employed in the film plays a key role in this respect, since the opening scenes of the film deliberately cause the viewer's eye to become gradually accustomed to both the spacious and luxurious interior of Vladimir's modern flat, as well as the almost indolent pace of the action and movement of the protagonists (Fig. 2). The shock is, therefore, all the greater as the journey takes the viewer progressively back into a different time-space dimension characterised by one of the quintessential images of communist-era East European life: the apartment. The director in no way mitigates the force of this effect, choosing rather to highlight the sense of incarceration by portraying Sergei framed, a solitary figure, on the middle balcony of a dilapidated block of flats. This is surely one of the most striking images in the film: as Elena approaches the apartment of her son on foot, we are presented with a medium shot of Sergei himself as he stands perfectly 
centred in the middle balcony of the apartment block, an image where geometry and culture intersect - humankind framed and defined by its living spaces with the historical context (here Soviet) also present. Sergei is smoking, and lets fall from his lips a ball of spit which he watches fall to the ground some distance below. Just as the film's opening scene makes it clear that we are dealing first and foremost with the theme of living spaces and their relation to human life, so here too we see the human race defined and contained by its living space. The descent of the ball of spit is determined by gravity as much as the life of this particular man is confined by the nonplace he is forced to inhabit. As Augé observes: "What he is confronted with, finally, is an image of himself... The space of non-place creates neither singular identity nor relations; only solitude and similitude" [Augé, p. 83].

Once the camera enters the apartment which belongs to Sergei and his wife Tanya, the cramped and stifling living conditions come to the fore and stand in direct contrast with the preceding scenes in the film. Whereas in Vladimir's apartment the camera has had the space to roam freely and rest on objects without inhibition, in Tanya and Sergei's apartment the camera cannot find the space to rest on anything, confined as it is by the cramped conditions and the people living there. There is an irony to this also: while the modern apartment certainly provides space and comfort, the camera is static, reflecting a curious lack of movement and dynamism on the part of the protagonists who live in it; although the camera, like the people who live there, has the freedom to roam and explore uninhibited by spatial restrictions, its movements are slow and unadventurous. By contrast, the restricted and somewhat squalid apartment of Sergei and Tanya results in a constant fluidity of camera movement, occasioned, of course, by the need to move in order to capture the protagonists, but, nevertheless, giving a sense of motion and life in comparison to the first apartment.

In this regard, Elena resembles another Russian film, Malen'kaia Vera/Little Vera (Pichul, 1988), which, we have argued previously [Lagerberg, McGregor], represents an ironic ode to the Soviet apartment. In both of these films the Soviet-era apartments are filmed in such a way that the impression given is one of intensely close and difficult living conditions. As Beardow writes, "The camera brilliantly catches the cramped conditions. When it tracks back, it is as if there is not enough room for it; it is almost squeezed out..." [Beardow, p. 16]. Of course, to a large degree, this is a direct result of the actual conditions of these apartments, namely that they are physically small and close and their inhabitants are in the low-income bracket; nevertheless, it seems that the atmosphere is deliberately heightened by the filming technique, rather than mitigated by it, precisely because the role of the apartments in both films is of primary importance. The role of the apartment in Little Vera certainly differs in some respects from that which it plays in Elena, most notably, perhaps, because in Little Vera the majority of the film is filmed in only one apartment. The apartment in Little Vera can be viewed as a cultural topos par excellence: as lack of living space represents the most tangible and visible manifestation of Soviet everyday life. This is represented time after time 
in Soviet literature and film, and Little Vera lays bare its completed journey from ideal of the Soviet state to a suffocating antithesis of liveable conditions. From the "noble" topos (common place) of the apartment as the necessary corequisite of (post)-revolutionary domestic living space, the apartment in this film becomes the absolute commonplace, where vulgarity (поилость) and everyday humdrum existence ( $6 \mathrm{~b} \mathrm{~lm})$ meet in a deadly combination, viz non-living space. As Svetlana Boym puts it in her seminal work on Soviet/ Russian mythologies of everyday life, "Common place refers to both the organization of space and the organization of speech. This trope has degraded through history: from the noble Greek topos, a site of classical argument, it has turned into the modern commonplace, the synonym for a cliche'" [Boym, p. 11]. The difference between the portrayal of the Soviet apartment in each film is essentially structural: whereas in Little Vera it is the central focus of the entire film, in Elena it represents the more obvious non-place and its cultural connotations from which Elena attempts to rescue her relatives. It, in turn, is counterbalanced by the less obvious non-place - the modern apartment to which her relatives are brought, but which is shown to be little more than an equally empty and meaningless space in cultural and philosophical terms.

In a curious way, however, the atmosphere in Sergei and Tanya's confined apartment is more life-affirming than in Vladimir's apartment. Although Sergei and his son continue to play on the computer in spite of Elena's arrival and Tanya's pleading for them to join them in the kitchen, the overall impression is of a family with at least some degree of interaction, though, of course, the close physical living conditions enforce that to some degree. Nevertheless, in this apartment, just as in Vladimir's, we are within the realm of the non-place again: the thudding sounds of the computer game echoing through the other rooms of the apartment are akin to the almost lifeless sounds of the televisions in Vladimir's apartment which are switched on de rigeur every waking hour of the day (and night). The squalor of Sergei's apartment block is clearly instrumental in moulding the identity of Sergei's son Alexander who, towards the end of the film, is involved in a violent fight for no apparent reason with another gang living on the same estate: domestic non-places lead to non-reason and to non-lives. Sergei's son's involvement with the gang is perhaps indicative of the struggle for identity experienced by all of Elena's family. Just as the young male seeks to have his identity bolstered by involvement with a group of equally lost and misguided delinquents, so too does Elena's family's rise - through social aspiration at all costs - seem to fall in line with Augés observation that: "The temptation to narcissism is all the more seductive... in that it seems to express the common law: do as others do to be yourself" [Augé, p. 85].

\section{The film's conclusion}

After Elena has murdered Vladimir and taken the required amount of money to her son, the film concludes with the "invasion" by Elena's relatives (Sergei and his family) into the late Vladimir's apartment, ostensibly on 
a permanent basis. One of the final images is that of Sergei and Tanya's youngest child, the baby. While in the cramped conditions of their Sovietera flat, the baby is never seen alone, but is constantly held by either mother or grandmother (Elena). With the move of Sergei's family to Vladimir's spacious apartment we see the rather disturbing image of the baby placed alone in a bedroom, indeed on Vladimir's deathbed, suggesting the overriding irony - that while living conditions here are vastly superior, there is also moral emptiness: the cuckoo has taken over the nest, but the nest determines lives and it will not bring to this invader any more joy than it did to the rightful owner. It also reiterates the ironic fact already mentioned that, notwithstanding the more difficult living conditions in Sergei and Tanya's apartment, the latter is nevertheless more full of vitality than the more luxurious apartment of Vladimir.

Prior to this scene, the film explores the question of Elena's feelings of guilt as she travels from her own apartment to that of her son's in order to deliver the ill-gotten money; the train journey, in particular, concentrates on the question of Elena's conscience even though it is made almost entirely without dialogue. For much of the journey Elena is depicted in close-up, her facial and hand movements betraying her sense of tension as the police stop the train before allowing it to move on again. In truth, it is perhaps not so much Elena's conscience which is troubled as the possibility of being arrested by the police, and it is this which momentarily changes the tenor of the film to that of a thriller. However, as the train moves off again after its brief stop, our attention is drawn by the comment "Look!" made by some other passengers and the shift of the camera to a horse which has fallen and apparently died or, perhaps, been struck down, near the railway crossing through which the train on which Elena is travelling passes. The image of the horse, coupled with the preceding sense of impending doom as a result of the murder committed, is obliquely, but unquestionably, connected with Dostoevsky, in particular Crime and Punishment, in Part 1 Chapter 5 of which Raskolnikov dreams of a mare being battered to death by a group of peasants. ${ }^{3}$ While the actual details differ in many essentials - the dream in Dostoevsky's novel occurs before the crime and acts more as a stimulus to the crime than as an examination of Raskolnikov's guilty conscience (see, for example: [Shaw, p. 135-136; Snodgrass, p. 232-233]), the scene in Elena serves to link the protagonist psychologically and morally with Raskolnikov in the Russian tradition and is certainly Dostoevskian in its tenor and its treatment of crime and conscience in an urban setting. However, the inevitable conclusion to be drawn from Elena is that the immoral act of murdering the innocent horse (i.e. Vladimir) plays a limited role in comparison to the drawn-out drama of Raskolnikov's battle with his own conscience: by the time Elena reaches the apartment of Sergei and Tanya her struggle appears to be over, as does the threat of any

\footnotetext{
${ }^{3}$ Other images of horses representing innocent victims of human cruelty in Russian literature are Vronsky's rough handling of the mare Frou-Frou during a horse race in Anna Karenina resulting in its death, and Mayakovski's poem «Хорошее отношение к лошадям» (Kindness to Horses), a moving account of a horse which falls in the street to the amusement of the passers-by.
} 
legal consequences. Just as traditional place becomes non-place in Elena, so traditional right and wrong become intertwined and ultimately vapid and meaningless in the supermodern world.

Just as the film opened to the lifeless awakening of Vladimir and Elena as their day begins, so at the film's end - the closing of the frame - the camera draws away after showing the vacuous scene of the new inhabitants making themselves comfortable and Sergei settling down to television and a bowl of snacks. From non-place 1 to non-place 2, the migration appears complete; yet, for the viewer, it seems far from final. The family's occupation of the post-Soviet living space seems in no way convincing as a long-term proposition, and one wonders how long it will take for these illegitimate interlopers to be "found out". Indeed, late in his book, Augé refers in one instance to the experience of non-place as being "out-of-place": a space in which one "tastes for a while... the passive joys of identity-loss, and the more active pleasure of role-playing" [Augé, p. 83, 91].

The final shot of the film, the closing frame as it were, takes us back out of the domestic space that Elena's family has claimed for itself and shows the apartment from a distance, perhaps yet another suggestion that this is simply another further evolution in a transitory existence. Ultimately it is the space itself that will most likely outlast and outlive its inhabitants as they pursue a universal goal of social aspiration through the acquisition of increasingly desirable living space: "A movement whose only end [is] itself", where people are as much in transit in their domestic space as they are, increasingly, in the ever more prominent non-places of shopping malls, airports and hotels. Augé also reaches the potentially disturbing conclusion that "in the world of supermodernity people are always, and never, at home" [Augé, p. 71, 87].

In a discussion of Soviet culture and living spaces, Boym discusses the iconography of a well-known 1952 Socialist Realist painting, The New Apartment, which portrays the arrival of a family in their "new" communal apartment:

The painting is neither reflective nor self-reflective: people and objects hardly cast any shadows here, and there is no mirror hidden in the corner. The scene flaunts its perfect bright visibility and transparency of meaning. $<\ldots>$ It is the way the culture wishes to see itself and to be seen, without thinking about the act of seeing. This is a perfect Socialist Realist genre scene, not an accurate portrayal of a Soviet apartment [Boym, p. 7].

The final scene in Elena in some ways represents an ironic inverse of this kind of image: while the Soviet apartment in Elena lays bare the shortcomings of that era's living spaces and the culture and ideology that gave rise to them, the modern apartment takes us almost full circle to the brave new world of spacious and luxurious living in Russia. The final scene of the modern apartment is, in a sense, a replica of that described by Boym above mutatis mutandis and with a liberal serving of irony 
thrown in. While the more squalid aspects of the Soviet apartment are now far removed (even Sergei's son now appears miraculously unscarred from his recent brawl), the metaphysical questions "What to do next? How to live?" seem to be answered by the promise of television, snacks and the solitary baby. In this way the film as a whole can be seen as a commentary on the wider debate of Russia's national identity, which goes back to the $19^{\text {th }}$ century and Chaadaev's first Philosophical Letter mentioned above. The film's ostensible premise of linear progression and concomitant progress from Soviet to post-Soviet is, as it were, framed in this final "family" scene, but, at the same time, the sense of cultural and moral emptiness which is highlighted by, for example, wide physical space, lack of movement and banal dialogue, only serves to undermine what is portrayed in this particular "painting". Rather than portraying a progression from non-place to place, the film offers a somewhat sombre appraisal of Russian national identity as a shift to just another instance of a non-national non-place characterised by the sense of universal displacement typical of supermodernity.

In conclusion, Elena depicts modern Russia through the prism of two non-places, the modern luxurious apartment and the more cramped and squalid Soviet-era flat. Identity is inextricably linked to physical space in the Russian context, and given that these living spaces represent non-places, the lives depicted in the film can be read, as we have done here, as non-lives. Though both living spaces scarcely possess any redeeming moral features, each shows a different aspect of Russian life. While the Soviet-era apartment is "warmer" in some ways, with more human life and contact, its indolence and decadence are toxic, most evidently in Alexander's character. The modern apartment is, by contrast, cold and tomb-like, lifeless and even non-specific with regard to nationality. The Soviet-era apartment resembles the setting of Malen'kaia Vera (Little Vera) (Pichul, 1988) with its lack of space and the camera forced to keep moving in order to film its interior. This contrasts with the static "widescreen" shots in the modern apartment, resembling still-life. Elena is the bridge between these two apartments; she constantly opens and closes the doors and curtains of the "tomb", preparing the stage, as it were, for Vladimir's demise and her family's somewhat dubious rise.

The aspiration to live in comfort, while human and understandable, is shown to result in a form of living death. However, the Soviet apartment, while not entirely lifeless, is just as suffocating, squalid and traps its inhabitants in a life of sloth and even violence. Through an ironic depiction of the more up-market apartment, what should have been viewed as a "move in the right direction" by Sergei and his family becomes, morally and culturally at least, little more than a move "out of the frying pan into the fire". Through its images, Elena is linked to Russia's literary and historical past, and offers a commentary on the centuries-old debate on Russia's identity and social progress (or lack thereof). As we have demonstrated, the dark images of Soviet and post-Soviet Russia provided 
by Zvyagintsev's powerful film represent the home as a transitory liminal space, indeed as a non-place: an aspiration, a fantasy, a shifting mirage, a perpetual transit lounge with the empty promise of social mobility in a supermodern world.

\section{Список литературы} $122 \mathrm{p}$.

Augé M. Non-Places: An Introduction to Supermodernity. $2^{\text {nd }}$ ed. L., N. Y., Verso, 2008.

At the Movies // ABC [site]. URL: http://www.abc.net.au/atthemovies/txt/s3509335. htm (mode of access: 28.01.2016).

Beardow F. Little Vera : Kinofiles Film Companion 8, I. B. Tauris, L., N. Y., 2003.

Boym S. Common Places : Mythologies of Everyday Life in Russia. Cambridge ; Massachusetts ; L. : Harvard University Press, 1994. 384 p.

Bradshaw P. Elena-review // The Guardian [site]. URL: http://www.theguardian.com/ film/2012/oct/25/elena-review (mode of access: 28.01.2016).

Chaadaev P. Letters on the Philosophy of History : First Letter // Russian Intellectual History : An Anthology / ed., transl. M. Raeff. N. Y. : Harcourt, Brace and World, 1966. P. $160-173$.

Clowes E. W. Russia on the Edge : Imagined Geographies and Post-Soviet Identity. Ithaca ; L. : Cornell University Press, 2011. 179 p.

Lagerberg R., McGregor A. Home Sweet Home : The Significance of the Apartment in the Film Malen'kaia Vera (Little Vera) // Studies in European Cinema. 2011. № 1 (8). P. 57-65.

Shaw J. T. Raskolnikov's Dreams // Slavic and East European J. 1973. № 2 (17). P. 131-145.

Snodgrass W. D. Crime and Punishment : The Tenor of Part One // The Hudson Rev. 1960. № 13. P. 202-253.

Thomassen B. Liminality // Routledge Encyclopedia of Social Theory / Eds. B. L. Harrington, Marshall \& H.-P. Müller. L.: Routledge, 2006. P. 322.

Van Baak J. The House in Russian Literature : A Mythopoetic Exploration. Amsterdam ; N. Y., Rodopi, 2009. 525 p.

\section{Список фильмов}

Пичул В. «Маленькая Вера». Россия : киностудия им. Горького, 1988. 128’.

Tati J. "Playtime". France: Jolly Film; Specta Films, 1967. 124'.

Truffaut F. "Les quatre cents coups" / "The 400 Blows". France: Les films du carosse; Sédif Productions, 1959. 99'.

Звягинцев А. «Елена». Россия: Non-Stop Productions, 2011. 109’.

\section{References}

Augé, M. (2008). Non-Places: An Introduction to Supermodernity. $2^{\text {nd }}$ ed. L., N. Y., Verso. $122 \mathrm{p}$.

At the Movies // ABC [site]. URL: http://www.abc.net.au/atthemovies/txt/s3509335. htm (mode of access: 28.01.2016). 2003.

Beardow, F. (2003). Little Vera. KINOfiles Film Companion 8, I.B. Tauris, L., N. Y.,

Boym, S. (1994). Common Places: Mythologies of Everyday Life in Russia. Cambridge, Massachusetts, L., England, Harvard University Press. 384 p.

Bradshaw P. Elena-review // The Guardian [site]. URL: http://www.theguardian.com/ film/2012/oct/25/elena-review (mode of access: 28.01.2016).

Chaadaev, P. (1966). Letters on the Philosophy of History: First Letter. In Raeff, M. (Ed., Transl.). Russian Intellectual History: An Anthology (pp. 160-173). N. Y., Harcourt, Brace and World. 
Clowes, E. W. (2011). Russia on the Edge: Imagined Geographies and Post-Soviet Identity. Ithaca, L., Cornell University Press. 179 p.

Lagerberg, R. \& McGregor, A. (2011). Home Sweet Home: The Significance of the Apartment in the Film Malen'kaia Vera (Little Vera). In Studies in European Cinema, 8/1, pp. 57-65.

Shaw, J. T. (1973). Raskolnikov's Dreams. In Slavic and East European J., 17/2, pp. 131-145.

Snodgrass, W. D. (1960). Crime and Punishment: The Tenor of Part One. In The Hudson Rev., 13, pp. 202-253.

Thomassen, B. (2006). Liminality. In Harrington, B. L., Marshall \& Müller, H.-P. (Eds.). Routledge Encyclopedia of Social Theory (p. 322). L.: Routledge.

Van Baak, J. (2009). The House in Russian Literature : A Mythopoetic Exploration. Amsterdam, N. Y., Rodopi. 525 p.

\section{Film References}

Pichul, V. (1988). Malen'kaia Vera (Little Vera). Soviet Union : Gorky Film Studios. 128 .

Tati, J. (1967). Playtime. France : Jolly Film; Specta Films. 124'.

Truffaut, F. (1959). Les quatre cents coups / The 400 Blows. France : Les films du carosse; Sédif Productions. 99'.

Zvyagintsev, A. (2011). Elena. Russia : Non-Stop Productions. 109’.

The article was submitted on 08.03.2016 